\title{
Improving the design of piles driven in chalk through the ALPACA research project
}

\author{
Richard James Jardine ${ }^{1, \star}$, Róisín Marie Buckley ${ }^{3}$, Byron Walter Byrne ${ }^{2}$, Stavroula Kontoe ${ }^{1}$, \\ Ross Alexander McAdam ${ }^{2}$, Thomas Andolfsson ${ }^{2}$, Ting Fa Liu ${ }^{1}$, Fabian Schranz ${ }^{2}$ and Ken Vinck ${ }^{1}$ \\ ${ }^{1}$ Imperial College London, London, UK \\ ${ }^{2}$ Oxford University, Oxford, UK \\ ${ }^{3}$ Oxford University, UK, formerly Imperial College London, Oxford, UK
}

\begin{abstract}
Chalk is present under large areas of NW Europe as a low-density, porous, weak carbonate rock. Large numbers of offshore wind turbines, bridges and port facilities rely on piles driven in chalk. Current European practice assumes ultimate shaft resistances that appear low in comparison with the Chalk's unconfined compression strength and CPT cone resistance ranges and can impact very significantly on project economics. Little guidance is available on pile driveability, set-up or lateral resistance in chalk, or on how piles driven in chalk can sustain axial or lateral cyclic loading. This paper describes the ALPACA (Axial-Lateral Pile Analysis for Chalk Applying multi-scale field and laboratory testing) project funded by EPSRC and Industry that is developing new design guidance through comprehensive field testing at a wellcharacterised low-to-medium density test site, supported by analysis of other tests. Field experiments on 36 driven piles, sixteen of which employ high resolution fibre-optic strain gauges, is supported by advanced laboratory and in situ testing, as well as theoretical analysis. The field work commenced in October 2017 and was largely complete in May 2019.
\end{abstract}

Keywords: driven piles / chalk / axial/lateral / monotonic/cyclic loading

Résumé - Le projet de recherche ALPACA pour améliorer le dimensionnement des pieux battus dans la craie. La craie est présente dans de vastes zones du nord-ouest de l'Europe sous forme de roche carbonatée peu dense, poreuse et tendre. Un grand nombre d'éoliennes en mer, de ponts et d'installations portuaires reposent sur des pieux battus dans la craie. Selon la pratique européenne actuelle, les résistances ultimes en frottement sur le fût des pieux semblent faibles comparées aux gammes de résistance à la compression simple et de résistance au cône CPT de la craie et peuvent avoir un impact très important sur l'économie du projet. Il existe peu de conseils sur la prédiction du battage des pieux, la cicatrisation du frottement ou la résistance latérale dans la craie, ou encore sur la manière dont les pieux enfoncés dans la craie peuvent supporter un chargement cyclique axial ou latéral. Ce document décrit le projet ALPACA (analyse du comportement axial et latéral des pieux dans la craie à partie d'une approche expérimentale à échelle multiple sur le terrain et en laboratoire). Ce projet, financé par l'EPSRC et l'industrie, s'attache à élaborer de nouvelles recommandations de dimensionnement en s'appuyant sur des séries d'essais réalisés sur un site bien caractérisé de craie de densité faible à moyenne et sur l'analyse complémentaire d'autres tests. Des essais sur le terrain ont été exécutés sur 36 pieux battus, dont seize utilisant des jauges de déformation à haute résolution en fibre optique. Ils sont étayés par des essais de laboratoire avancés et des essais in situ, ainsi que par des analyses théoriques. Les travaux sur le terrain ont commencé en octobre 2017 et se sont quasiment terminés en mai 2019.

Mots clés : pieux battus / craie / axial/latéral / chargement monotone/cyclique

\footnotetext{
$\bar{\star}$ Corresponding author: $r$ jardine@imperial.ac.uk
} 


\section{The need for research into pile behaviour in chalk}

Chalk is present under the NW European area shown in Figure 1 and is often encountered in regional geotechnical investigations for ports, roads, railways, commercial/domestic buildings, industrial plants/utilities, as well as offshore oil, gas and wind-energy installations. While bored and Contineous Flight Augering (CFA) piles are selected for many applications, large open-ended steel tubular driven piles are employed for most offshore and nearshore developments (see Lord et al., 2002; Jardine et al., 2018). Over two thirds of the world's currently operating offshore wind generating capacity is installed in UK and German waters and multiple wind-farms are being developed at UK, Danish, French and German sites where chalk dominates design.

The generally white low-density, structured very finegrained porous weak carbonate rocks encountered (often with silica flint nodules and layers) pose difficulties to engineers seeking to design the high capacity, often large diameter, tubular steel piles that routinely support offshore structures. Designers seeking to ensure satisfactory performance have only limited guidance regarding axial and lateral capacity and stiffness. Pile driving problems are also common.

Ciavaglia et al. $(2017 \mathrm{a}, \mathrm{b})$ report some of the only available lateral pile load tests in chalk. In addition, very few high quality static axial pile tests have been carried out. Existing CIRIA C574 design recommendations (Lord et al., 2002) reflect this uncertainty. Their axial design method was derived from the database shown in Figure 2, where average shaft resistance, $\tau_{\mathrm{avg}}$, is plotted against average overburden pressure, $\sigma^{\prime}{ }_{\text {vo. }}$. Just six tests of mixed quality were identified that involved open-ended piles driven at four sites; two with lowmedium density chalk (Hobbs and Robins, 1976; Burland and French, 1990) and two with high density chalk (Lord and Davies, 1979; Hobbs and Atkinson, 1993). The CIRIA C574 and earlier CIRIA PR11 guide (Lord et al., 1994) recommendations superseded the CIRIA PG6 effective stress method (Hobbs and Healy, 1979), due to concerns about the apparent lack of correlation between $\tau_{\text {avg }}$ and $\sigma_{\text {vo }}^{\prime}$ shown in Figure 2 and concerns over the database size and quality.

Although even low-to-medium density NW European Chalks have relatively high Unconfined Compressive Strengths (UCS) (up to $5 \mathrm{MPa}$; Bowden et al., 2002), and cone tip resistances, $\mathrm{q}_{\mathrm{c}}$ (4 to $50 \mathrm{MPa}$; Power, 1982), the limited dataset of tests suggests that small displacement (open-ended) driven piles mobilise:

- very low $(8-42 \mathrm{kPa}) \tau_{\text {avg }}$ values in low-medium density chalks, comparable to those expected in very soft to soft clays, that do not appear to increase with depth or $\sigma_{\text {vo }}^{\prime}$;

- markedly higher $\tau_{\text {avg }}(125-150 \mathrm{kPa})$ in medium-high density chalk.

The CIRIA guidelines recommend taking ultimate shaft resistances of $120 \mathrm{kPa}$ for high density chalk and $20 \mathrm{kPa}$ in all other densities and grades, reducing to $10 \mathrm{kPa}$, if the pile can "whip". These recommendations lead to stark choices for designers in variable chalk ground conditions, which impact significantly on project economics (see Barbosa et al., 2017).

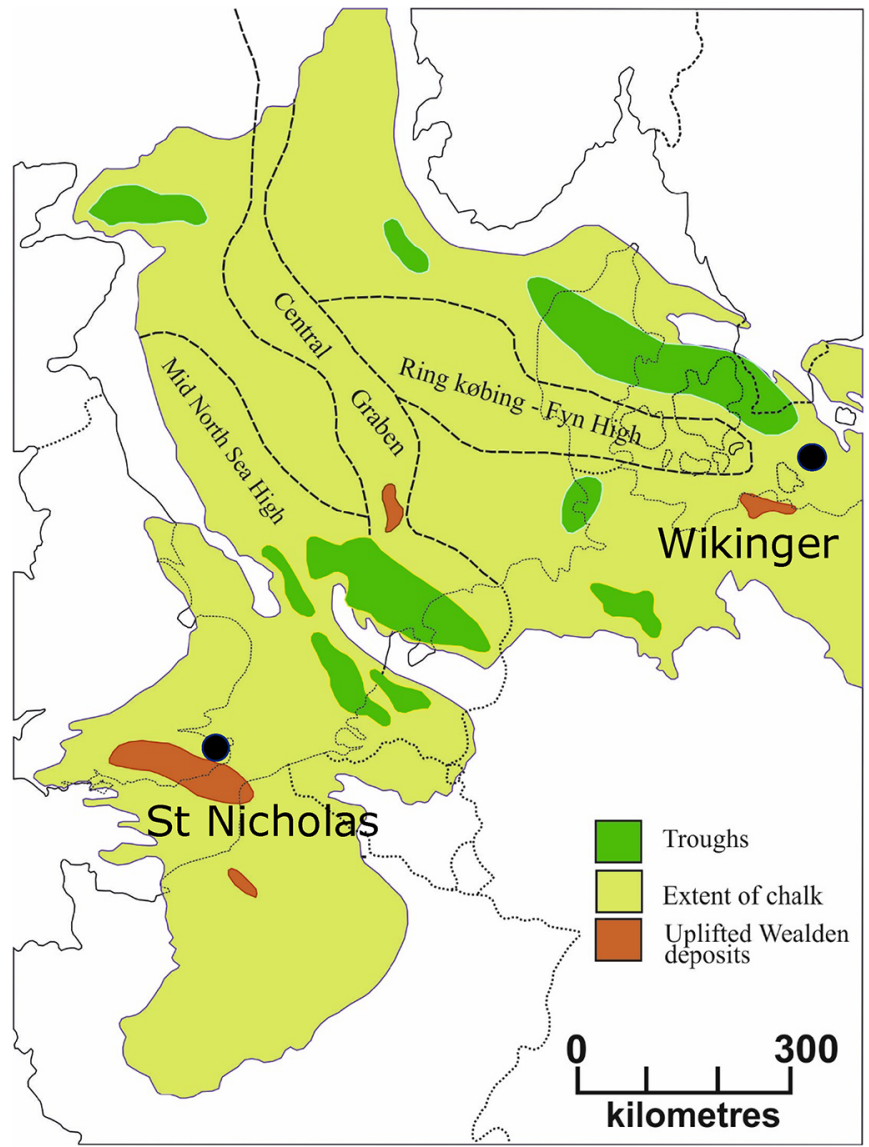

Fig. 1. Chalk of NW Europe, after Mortimore (2012) also showing the Wikinger and St Nicholas-at-Wade test site locations.

Fig. 1. La craie au Nord-Ouest de l'Europe, d'après Mortimore (2012) avec indication des sites de Wikinger et St Nicholas-at-Wade.

Lord et al. (2002) suggest that site-specific pile load tests should be undertaken wherever possible.

Pile refusals have been reported on driving through hard high-density chalk. However, piles installed at low-to-medium density offshore windfarm sites have penetrated (or "run") to considerable depths under their self-weights (see for example Carotenuto et al., 2018). Driving is thought to destructure the high porosity material, leaving a low strength "putty" around the shaft (Hobbs and Atkinson, 1993). Such low shear resistances can be matched by applying high level cyclic loading in laboratory simple shear tests (Carrington et al., 2011) or by Proctor laboratory compaction of intact samples at their natural water contents (Doughty et al., 2018). However reports of offshore pile runs prove that very low shaft stresses can develop without cycling. Low installation resistances may also be explained by attenuation of stresses with increasing relative distance from the pile tip, $h$, as the pile penetrates, such as is also observed in clays and sands (see Jardine et al., 2005).

\section{The innovate UK JIP}

A clear need exists for more reliable, comprehensive and ideally effective-stress based procedures for assessing 


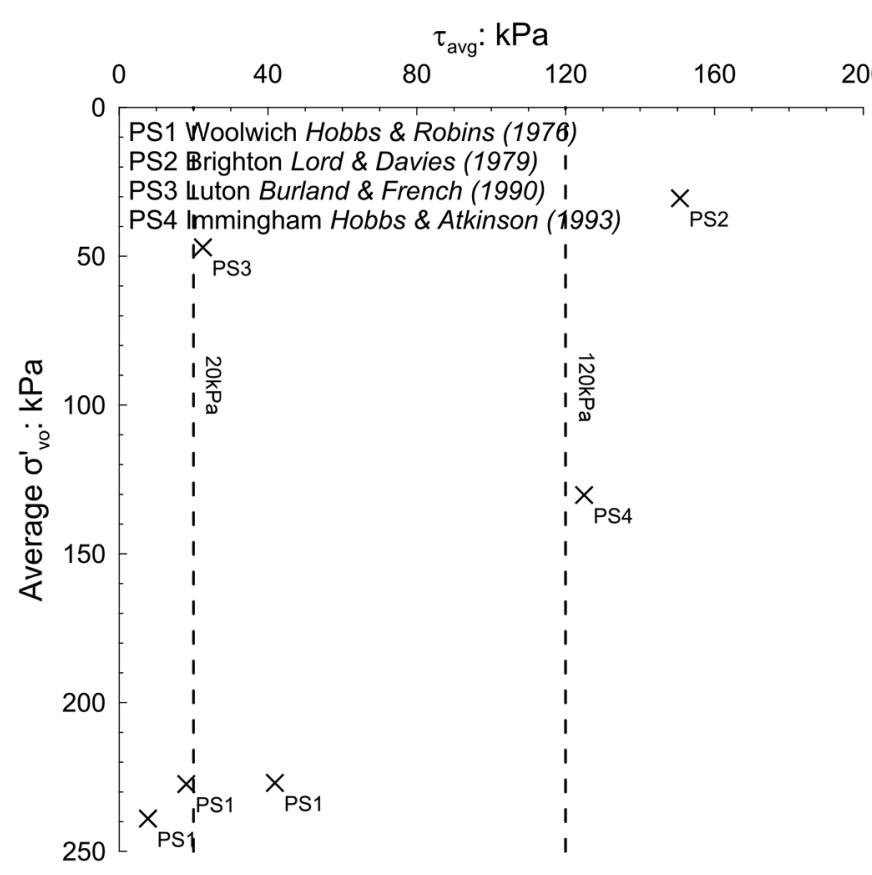

Fig. 2. Average shaft resistance for tests on open-ended steel piles from CIRIA C574 (Lord et al., 2002) database.

Fig. 2. Résistance axiale moyenne le long du fût déduite de la banque de données CIRIA sur des pieux en acier ouverts à la base (CIRIA C 574 ; Lord et al., 2002).

driveability and load-deformation behaviour for piles driven in chalk. Information on the set-up characteristics of "virgin" piles is required, as is guidance on the piles' responses to lateral and cyclic loading.

An Innovate-UK funded Joint Industry Project (JIP) study was undertaken between 2014 and 2017 to meet this need by combining industrial and academic research that has been reported by Barbosa et al. (2017), Buckley (2018), Buckley et al. (2018a, b, c, 2019a, b), Jardine et al. (2018). The objectives were to: (i) develop new methods of field pile testing and analysis; (ii) expand the database of high quality field measurements; and (iii) produce new design rules comparable to the ICP-05 procedures developed through earlier research for use in sand and clay strata $(\mathrm{ICP}=$ Imperial College Pile).

The Innovate UK JIP encompassed field experiments conducted at two low-to-medium density chalk test sites. These comprised an onshore programme at St Nicholas-atWade in Kent (UK) combined with very high value offshore tests at the Wikinger windfarm in the German Baltic. Multiple dynamic (compressive) measurements of pile behaviour were made during driving, as well as later dynamic and static tension and cyclic loading experiments.

The research gave crucial new insights into the basic mechanisms of behaviour and the strong field ageing processes, leading to new preliminary effective stress design methods that: (i) offer more reliable predictions for static axial capacity; and (ii) consider cyclic loading, which is a key issue for many offshore oil, gas and wind-turbine foundations. The results of the Innovate-UK research are further summarised in these proceedings by Buckley et al. $(2019 \mathrm{a}, \mathrm{b})$.

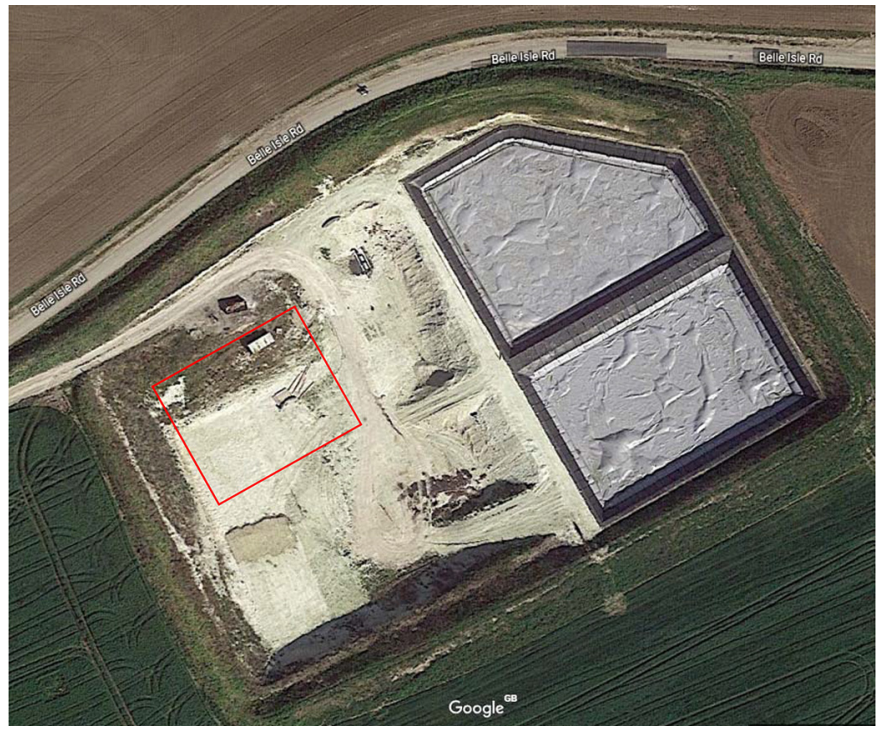

Fig. 3. Aerial view from Google Earth of St Nicholas-at-Wade test site showing approximate test area for ALPACA JIP programme.

Fig. 3. Vue aérienne extraite de Google Earth du site de St Nicholasat-Wade montrant la zone approximative des essais du programme collaboratif ALPACA.

The Innovate-UK JIP's field tests included four static tests to failure on virgin piles. However, only one of these was conducted on an industrial scale pile. The cyclic loading tests concentrated on one-way tension loading only and none of the driven piles were instrumented to measure shaft stresses under static or cyclic loading. While the programme was fully successful, more comprehensive research was required that extended to cover further cases, including static and cyclic lateral loading.

\section{The ALPACA JIP}

This paper outlines the ALPACA JIP research project which is underway to investigate a far wider range of axial and lateral cyclic loading conditions through high quality tests on 36 driven piles, sixteen of which are instrumented with novel fibre-optic strain gauge sensors.

The pile testing is supported by parallel laboratory research, in situ testing and careful analysis. ALPACA is funded by the UK's EPSRC (Grant EP/P033091/1) in conjunction with seven offshore wind developers (Iberdrola, Innogy, LEMS, Ørsted, Parkwind, Siemens and Statoil) and four consulting organizations (Atkins, Cathie Associates, Fugro and GCG). The JIP, which is led by an Academic Work Group from Imperial College London and Oxford University, aims to advance the design of tubular piles driven in chalk, particularly for offshore wind-turbines.

The field work is being conducted over two years at the onshore test site located at St Nicholas-at-Wade, in Kent SE England, that was employed previously by Ciavaglia et al. $(2017 \mathrm{a}, \mathrm{b})$ and by the Innovate UK JIP. The facility comprises a previous chalk quarry located at TR 2541966879 on the UK Grid. Figure 3 shows an aerial site view, while Figure 4 shows the piling operations undertaken in November 2017. 


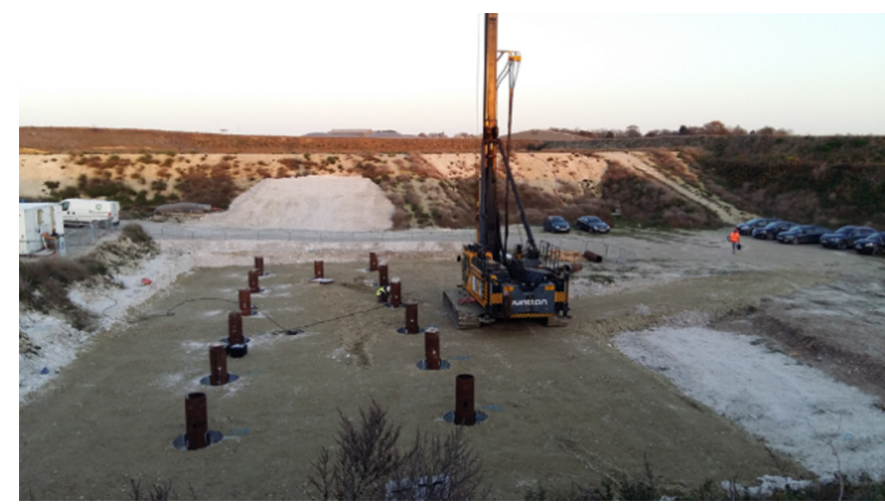

Fig. 4. Piling operations underway at St Nicholas-at-Wade for ALPACA JIP programme.

Fig. 4. Installtion des pieux en cours sur le site de St Micholas-atWade pour le programme collaboratif ALPACA.

A total of fourteen $508 \mathrm{~mm}$ OD instrumented piles have been driven, 12 to a depth of $10.15 \mathrm{~m}$ and two to $3.05 \mathrm{~m}$. The piles were allowed to age for several months before being subjected to a carefully programmed series of static and cyclic, axial and lateral loading tests.

Thirteen of the piles have been instrumented with opposing pairs of fibre-optic strain gauges strings (see Doherty et al., 2015), which were monitored during driving, giving valuable stress wave data before being employed for later static and cyclic tests. One $508 \mathrm{~mm}$ OD pile was instrumented with gauges on opposing faces of two perpendicular axes. Dual axis lateral cycling tests were conducted on this pile with full monitoring throughout. The cyclic tests typically involved 1000-2000 cycles per test stage, and in one case up to 100000 cycles.

A further twenty two $139 \mathrm{~mm}$ to $200 \mathrm{~mm}$ OD piles have been driven to depths of between 5.5 and $11 \mathrm{~m}$, which have been subjected to static and cyclic axial loading tests after ageing. Open and closed ends have been employed and pairs of fibre-optic strings have been installed on two of the piles. While eleven smaller piles were driven from ground level, five were installed through $6.3 \mathrm{~m}$ deep cased pre-bored holes, so that their shafts only engage the chalk at depths below the water table. The spread of experiments provides detailed insight into pile installation effects and the processes of ageing in situ. The piles were installed by Green Piling of Sheffield (UK) and around $2 / 3$ of the field testing is being conducted in conjunction with the company SOCOTEC.

Pile Driving Analysis (PDA) strain gauge and accelerometer instruments were applied to all piles during installation and the signals were analysed carefully prior to the static and cyclic loading tests. Analysis of the strain gauge data gathered from the lateral loading tests is assessed against the procedures developed in the earlier PISA Joint Industry Project reported by Byrne et al. (2017).

\section{The ALPACA site profile}

All overburden and weathered chalk has been removed at the test site, which has similar chalk to that encountered

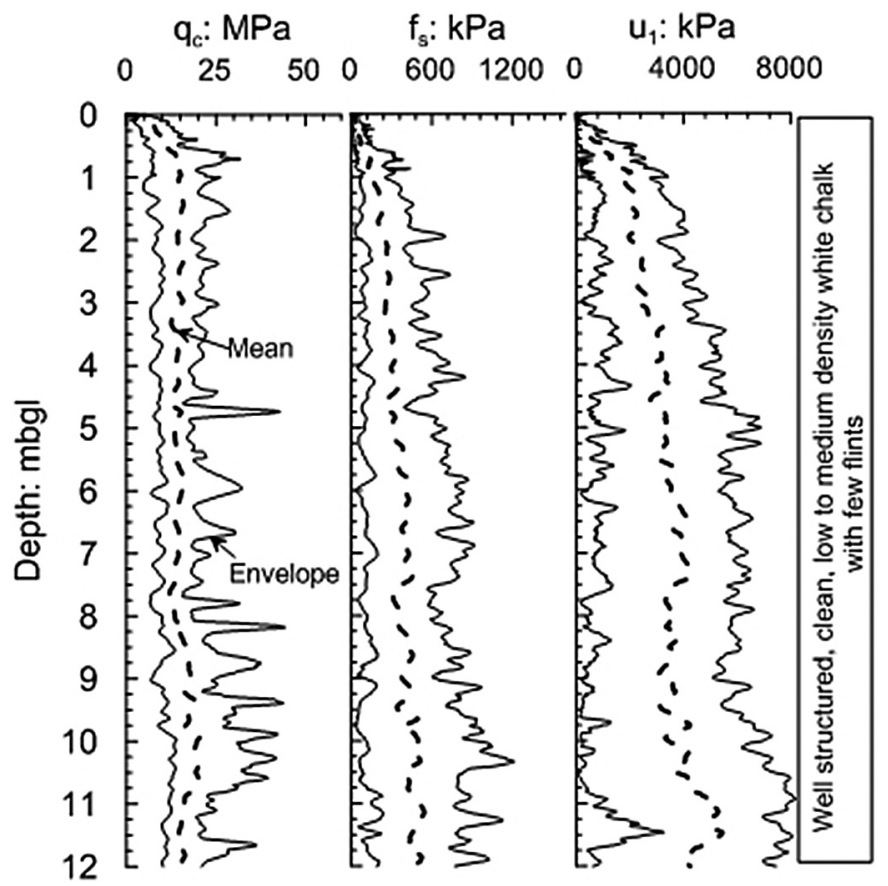

Fig. 5. Piezocone profiles at the St. Nicholas-at-Wade site.

Fig. 5. Profils au piezocône sur le site de St Nicholas-at-Wade.

(at greater depth) offshore at Wikinger. Earlier investigations have included five boreholes to a maximum $20.5 \mathrm{~m}$ depth and cone penetration tests with pore pressure measurement (PCPT) to $17 \mathrm{~m}$, along with laboratory testing (Fugro, 2012a, b).

Intensive new piezocone, seismic CPT and full penetration-pressuremeter testing has been conducted for ALPACA, while three $15 \mathrm{~m}$ deep Geobor-S boreholes and block sampling from $4 \mathrm{~m}$ deep test pits has provided high quality samples for a parallel laboratory element testing programme at Imperial College London that characterises chalk behaviour under static and cyclic conditions through advanced stress-path testing. Highly instrumented Mini-ICP model pile (see Jardine et al., 2009) installations have also been undertaken and piezometers and tensiometers have been installed to give detailed information on ground water conditions.

Over the investigation depths considered, the St Nicholasat-Wade (SNW) chalk classifies as CIRIA Grade B2/B3 (structured low-medium density), with discontinuities open to less than $3 \mathrm{~mm}$ and a fracture spacing of between 60 and $200 \mathrm{~mm}$. The water table lies at around $6 \mathrm{~m}$ depth. The chalk's Intact Dry Density (IDD) ranges from 1.38 to $1.54 \mathrm{mg} / \mathrm{m}^{3}$ over the pile depths, indicative of a low-density material.

The average Unconfined Compressive Strength (UCS) $q_{u} \approx 2.1 \mathrm{MPa}$ is within the range expected. As shown in Figure 5, CPT tests indicate a range of $5<q_{t}<35 \mathrm{MPa}$ with higher resistances in flint bands. Very high excess pore pressures are recorded at the $u_{1}$ cone face piezocone position. Lower, but still considerable, pressures develop at the $u_{2}$ cone shoulder location; Buckley (2018). The chalk fails in compression and starts to destructure under the high cone tip stresses developed in CPT tests, but retains sufficient shearing resistance to give sleeve resistances of up to $1 \mathrm{MPa}$, as it flows around the cone shoulders (see Fig. 2). 


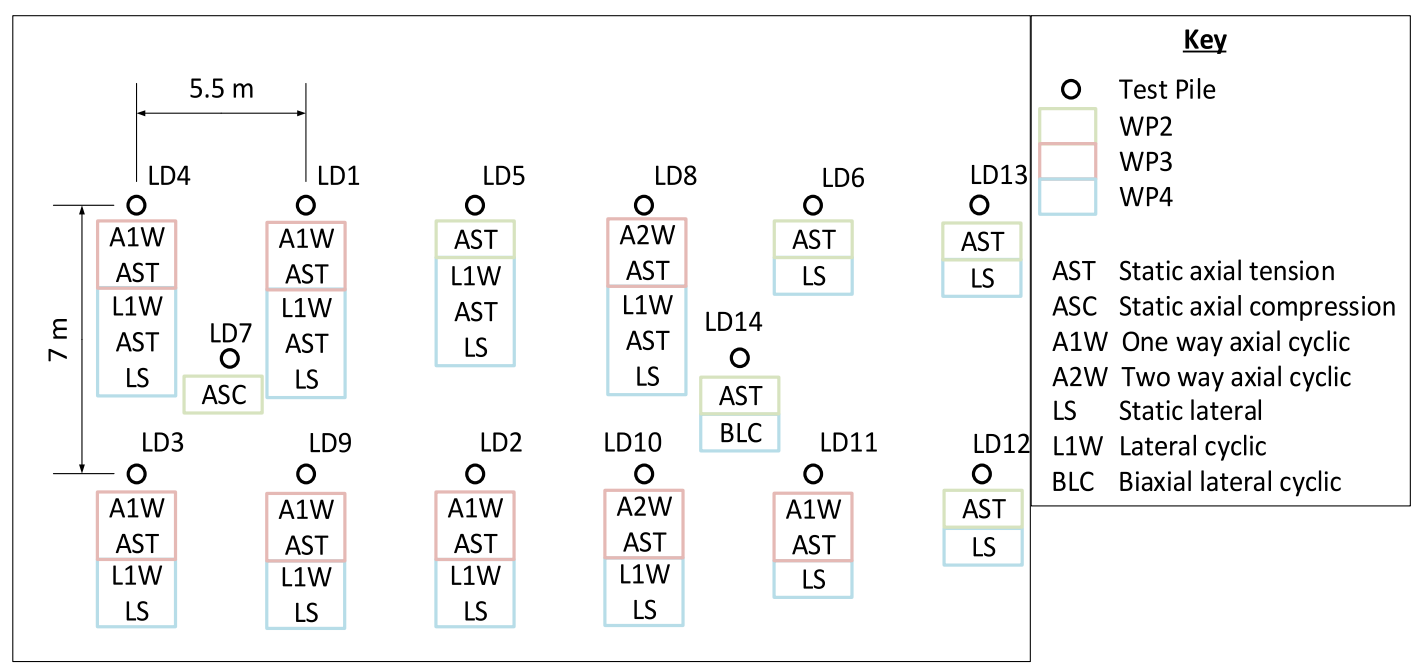

Fig. 6. Sequences of tests on the $508 \mathrm{~mm}$ OD piles, summarised on a local site plan.

Fig. 6. Séquence d'essais sur les pieux de $508 \mathrm{~mm}$ de diamètre extérieur, résumée sur un plan du site local.

\section{The ALPACA test sequences}

The ALPACA field testing programme comprises a main set of experiments on the fourteen $508 \mathrm{~mm}$ OD steel tubular piles, twelve of which are driven to $10.15 \mathrm{~m}$ and two of which are driven to $3.05 \mathrm{~m}$. Thirteen piles are instrumented on opposing faces with two strings of fibre optic strain gauges; one pile has additional opposing gauges in the perpendicular axis. Twelve of the $508 \mathrm{~mm}$ piles were installed in November 2017, and one additional pile was driven in May 2018. All were tested over the June to October 2018 summer period.

As outlined below and in Figure 6, the experiments on $508 \mathrm{~mm}$ OD piles were supplemented by further tests on $139 \mathrm{~mm}$ to $200 \mathrm{~mm}$ OD piles made from a range of steels and also reinforced concrete. These experiments allow separate consideration of: (i) how ageing and set-up depends on the pile material and (ii) the influence of the depth to the water table by including piles that were driven either entirely above, or solely below, the phreatic surface. The smaller pile test series also offer an opportunity to explore how piles driven above the water table respond to a wide range of one-way and two-way axial cyclic loading conditions.

The $508 \mathrm{~mm}$ OD pile loading tests were performed in a carefully programmed sequence that allowed for significant pile ageing processes to progress over specified periods before any loading commenced. Following an initial set of static tension and compression axial load tests, a total of 13 axial cyclic tests have been performed on previously unfailed piles. Most tests involved up to 1000 cycles of loading, applied with $10 \mathrm{~s}$ periods. Some tests failed at earlier stages and one was continued to 10000 cycles. Six of the cyclic tests involved purely tension (one way) loading, while a further 7 considered both compresison and tension cycling, leading to a similarly wide range of stable, metastable and unstable responses to that reported for piles driven in sands by Jardine and Standing (2012).

The fibre optic strain gauges provided key information on the monotonic and cyclic load transfer mechanisms. The impact of earlier axial cyclic loading on axial monotonic capacity was checked through final load tension tests to failure.
Noting that axial failure affected only a thin annulus of chalk around the pile shafts, the $508 \mathrm{~mm}$ piles were also employed for lateral loading tests, which engaged a far larger volume of high stiffness chalk. In addition to monotonic load tests to lateral failure, seven combinations of uni-directional lateral cyclic loading were applied to the piles; dual axis loading was applied in cyclic tests performed on the pile with perpendicular strain gauge pairings.

The $508 \mathrm{~mm}$ OD piles were fabricated from a special high yield strain X80 grade steel that allowed geotechnical failure to be achieved under lateral loading before the steel walls yielded. The fibre-optic strain gauge data is being assessed to derive information on the local lateral load-displacement behaviour of the piles under both monotonic and cyclic conditions.

As outlined in Figure 6, static lateral tests to failure were conducted after most lateral cyclic tests, followed by axial tension tests to failure that identified how lateral failure affects axial capacity.

\section{Summary and conclusions}

This paper has outlined the background to the ongoing ALPACA research project into driven pile behaviour in Chalk and described the scope of this Joint Industry research Project (or JIP). The project's principal aim is to support the developments of offshore wind turbine projects in areas that present chalk foundation conditions and enable safe and economical design under a wide range of loading conditions.

The main points raised in connection with the project are:

- while piles are driven routinely in chalk for offshore wind turbines, bridges and port facilities, current guidance on their axial capacity, driveability, set-up or lateral resistance is limited, as is knowledge of how such piles respond to axial or lateral cyclic loading;

- the ALPACA project addresses this gap in knowledge through comprehensive field-testing at a well-characterised low-to-medium density site, supported by analysis of other tests; 
- the field experiments are enhanced through the use of high resolution fibre-optic strain gauges and supported by advanced laboratory and in situ testing, as well as theoretical analysis;

- the field work, which commenced in October 2017 and ended in mid-2019, led to new findings concerning axial and lateral behaviour of piles under static, dynamic and cyclic loading conditions. These outcomes are currently being integrated with the laboratory and in situ programmes. Multiple publications on these findings will be presented after the JIP reaches its conclusion in 2020.

Acknowledgements. The Authors express their gratitude to EPSRC (Grant EP/P033091/1), Iberdrola, Innogy, LEMS, Ørsted, parkwind, Siemens and Statoil; as well as Atkins, Cathie Associates, Fugro and GCG, whose financial support and guidance is appreciated greatly. The Authors also acknowledge the major contributions of SOCOTEC and Green Piling to the field work as well as those made by colleagues at Imperial College London and Oxford and the assistance provided by Lankelma and Cambridge Insitu.

\section{References}

Barbosa PM, Geduhn M, Jardine RJ, Schroeder FC. 2017. Large scale offshore static pile tests-practicality and benefits. Proc 8th Int Conf on Offshore Site Investigation and Geotechnics, London, UK, pp. 644-651.

Bowden AJ, Spink TW, Mortimore RN. 2002. The engineering description of chalk: Its strength, hardness and density. $Q J E n g$ Geol Hydrogeol 35(4): 355-361.

Buckley RM. 2018. The axial behaviour of displacement piles in chalk. PhD Thesis, Imperial College London, London, UK.

Buckley RM, Jardine RJ, Kontoe S, Barbosa P, Schroeder FC. 2018a. Full-scale observations of offshore piles driven in chalk and glacial tills: Field behaviour under dynamic and static axial loading. Submitted to Geotechnique. Géotechnique (in press).

Buckley RM, Jardine RJ, Kontoe S, Parker D, Schroeder FC. 2018b. Ageing and cyclic behaviour of axially loaded piles driven in chalk. Géotechnique 68(2): 146-161. DOI: 10.1680/jgeot.17.P.012.

Buckley RM, Jardine RJ, Kontoe S, Lehane BM. 2018c. Effective stress regime around a jacked steel pile during installation ageing and load testing in chalk. Can Geotech J. DOI: 10.1139/cgj-2017-0145.

Buckley RM, Jardine RJ, Kontoe S, Barbosa P, Schroeder FC. 2019a. The design of axially loaded driven piles in low-medium density chalk. Proc XVII Eur Conf Soil Mech and Geotech Eng. Reykjavik, Iceland: Pub. ECSMGE. ISBN 978-9935-9436-1-3. DOI: 10.32075/ 17ECSMGE-2019-161.

Buckley RM, Kontoe S, Jardine RJ, Schroeder FC, Barbosa P. $2019 \mathrm{~b}$. Pile driveability in low to medium density chalk. Submitted (in preparation).

Burland JB, French DJ. 1990. Results of trials in weathered chalk of a novel piling system - The wedge pile. Proc Intl Chalk Symposium, Brighton, UK, pp. 375-383.

Byrne BW, McAdam RA, Burd HJ, et al. 2017. PISA: New design methods for offshore wind turbine monopiles. Keynote. Proc 8th Int Conf on Offshore Site Investigations and Geotechnics, SUT London, Vol. 1, pp. 142-161.
Carotenuto P, Meyer V, Strøm PJ, Cabarkapa Z, St. John H, Jardine RJ. 2018. Installation and axial capacity of the Sheringham Shoal offshore wind farm monopiles - A case history. In: Lawrence JA, Preene M, Lawrence UL, Buckley R, eds. Engineering in chalk. London: Pub. ICE, pp. 117-122.

Carrington TM, Li G, Rattley MJ. 2011. A new assessment of ultimate unit friction for driven piles in low to medium density chalk. Proc 15th Eur Conf Soil Mech \& Geotech Eng, Amsterdam, The Netherlands, pp. 825-830.

Ciavaglia F, Carey J, Diambra A. 2017a. Time-dependent uplift capacity of driven piles in low to medium density chalk. Geotechn Lett 7(March): 1-7.

Ciavaglia F, Carey J, Diambra A. 2017b. Monotonic and cyclic lateral tests on driven piles in chalk. Proc ICE Geotech Eng 170(4): 353-366.

Doherty P, Igoe D, Murphy G, et al. 2015. Field validation of fibre Bragg grating sensors for measuring strain on driven steel piles. Geotechn Lett 5: 74-79.

Doughty L, Buckley RM, Jardine RJ. 2018. Laboratory testing of chalk. In: Lawrence JA, Preene M, Lawrence UL, Buckley R, eds. Engineering in chalk. London: Pub. ICE, pp. 695-702.

Fugro. 2012a. Onshore geotechnical report: Field data St. Nicholas at Wade UK, Fugro Geoconsulting Ltd., Report D34001-1. Wallingford, UK.

Fugro. 2012b. Laboratory testing report: Pile test site, chalk specific testing. St. Nicholas at Wade, UK, Fugro Geoconsulting Ltd., Report D34001-2, Wallingford, UK.

Hobbs NB, Atkinson MS. 1993. Compression and tension tests on an open-ended tube pile in chalk. Ground Engineering 26(3): 31-34.

Hobbs NB, Healy PR. 1979. Piling in chalk report PG 6. London, UK: CIRIA.

Hobbs NB, Robins P. 1976. Compression and tension tests on driven piles in chalk. Géotechnique 26(1): 33-46.

Jardine RJ, Standing JR. 2012. Field axial cyclic loading experiments on piles driven in sand. Soils Found 52(4): 723-736.

Jardine RJ, Chow FC, Overy RF, Standing JR. 2005. "ICP design methods for driven piles in sands and clays". London: Thomas Telford Ltd, $105 \mathrm{p}$.

Jardine RJ, Zhu B, Foray P, Dalton CP. 2009. Experimental arrangements for the investigation of soil stresses developed around a displacement pile. Soils Found 49(5): 661-673.

Jardine RJ, Buckley RM, Kontoe S, Barbosa P, Schroeder FC. 2018. Behaviour of piles driven in chalk. In: Lawrence JA, Preene M, Lawrence UL, Buckley R, eds. Keynote, Engineering in chalk. London: Pub. ICE, pp. 33-52.

Lord JA, Davies JAG. 1979. Lateral loading and tension tests on a driven cased pile in chalk. Proc ICE Conf on Recent Developments in the Design and Construction of Piles, London, UK, pp. 113-120.

Lord JA, Twine D, Yeow H. 1994. Foundations in chalk report, PR11. London, UK: CIRIA.

Lord JA, Clayton CR, Mortimore RN. 2002. Engineering in chalk, C574. London, UK: CIRIA.

Mortimore RN. 2012. The 11th Glossop Lecture: Making sense of chalk: A total-rock approach to its engineering geology. $Q J$ Eng Geol Hydrogeol 45: 252-334.

Power P. 1982. The use of the electric static cone penetrometer in the determination of the engineering properties of chalk. Proc 2nd Eur Symp on Penetration Testing, Amsterdam, The Netherlands, pp. 769-774.

Cite this article as: Richard James Jardine, Róisín Marie Buckley, Byron Walter Byrne, Stavroula Kontoe, Ross Alexander McAdam, Thomas Andolfsson, Ting Fa Liu, Fabian Schranz, Ken Vinck. Improving the design of piles driven in chalk through the ALPACA research project. Rev. Fr. Geotech. 2019, 158, 2. 